\title{
Effect of Ethanol Extracts of Musa paradisiaca Fruit Pulp and Peels on Haematological Indices and Liver Enzymes of Experimental Rats
}

\author{
Emuesiri Goodies Moke ${ }^{1, *}$, Emuesiri Kohworho Umukoro ${ }^{1}$, Evelyn Tarela Ojugbeli ${ }^{2}$, Theresa Ezedom ${ }^{2}$, \\ Tarela Melish Elias Daubry ${ }^{3}$, Iziegbe Lisa Omorodion ${ }^{1}$ \\ ${ }^{1}$ Department of Pharmacology and Therapeutics; ${ }^{2}$ Department of Medical Biochemistry; ${ }^{3}$ Department of Physiology, \\ Faculty of Basic Medical Sciences, Delta State University, Abraka, Nigeria \\ Corresponding author* \\ hiligoodies@gmail.com
}

Manuscript received: 12 February, 2021. Revision accepted: 19 July, 2021. Published: 29 July, 2021.

\begin{abstract}
Medicinal plants usage in traditional medicine has risen over the years. Musa paradisiaca has been reported that it possesses various therapeutic efficacies. This study is aimed at evaluating the effect of parts of the ethanol fruit extracts of Musa paradisiaca on haematological indices and serum liver enzymes. Thirty Wistar rats were grouped into five groups of six animals each which were administered $200 \mathrm{mg} / \mathrm{kg}$ and $400 \mathrm{mg} / \mathrm{kg}$ of Musa paradisiac fruit (MPF) pulp extract or peel extract. Haematological indices and liver enzymes were assayed for at the end of the 14-days experimental period. MPF pulp and MPF peel at $400 \mathrm{mg} / \mathrm{kg}$ showed a significant $(\mathrm{P}<0.05)$ increase in red cell count and haematocrit level as compared to the control. There was a non-significant $(\mathrm{P}>0.05)$ increase in haemoglobin concentration in the treated rats as compared to the control. There was also a non-significant $(\mathrm{P}>0.05)$ change in AST, ALT, and ALP level of the treated rats as compared to the control. Fruit pulp and peel of Musa paradisiaca improve erythrocytes count and haematocrit level, and they may not be associated with liver toxicity.
\end{abstract}

Keywords: Anaemia; Haematology; Liver enzymes; Medicinal plants; Musa paradisiaca.

\section{INTRODUCTION}

Plants possess the ability to synthesize a variety of chemical compounds with various biological functions. The plant kingdom remains a harvest for many species of plants with key medicinal value which are yet to be discovered. Reports show that a large population (80\%) of people in developing countries depend primarily on medicinal plants for their primary health care (Mahomoodally, 2013; Ekor, 2014). These plants and herbs are taken in different ways and forms (whole or in parts) for the alternative management of diseases traditionally (Benzie and Wachtel-Galor, 2011; Emudainohwo et al., 2015; Moke et al., 2019; Okafo et al., 2019).

Musa paradisiaca belongs to Musaceae family and is popularly known as plantain. The plant is widely distributed in the Southern part of Nigeria, West and East Africa, Malaysia, Cameroun and Southern parts of United States (Uwaoma, 2003; Nayar, 2010). Musa paradisiaca (Plantain) is an important staple crop that contributes to the calories and substance economic in Africa (Oyeyinka and Afolayan, 2019). Abundant medicinal activities of parts of Musa parasidiaca have been reported. It has been shown to possess hepatoprotective activity (Nirmala et al, 2012; Issa et al.,
2018) as well as antidiabetic (Vilhena et al., 2020), antiulcer (Onasanwo et al., 2013; Ezekwesili et al., 2014; Moke et al., 2017), antimicrobial (Fagbemi et al., 2009), wound healing (Agarwal et al. 2009), and antioxidant properties (Yin et al., 2008).

The present study is aimed at evaluating the effect of parts of the ethanol fruit extracts of Musa paradisiaca on haematological indices and serum liver enzymes.

\section{MATERIAL AND METHODS}

\section{Plant Collection and Preparation}

Musa paradisiaca fruits (unripe) were purchased locally from the market, and were identified and authenticated by a taxonomist with existing specimen deposited at the herbarium of the Department of Botany, Delta State University, Abraka, Nigeria. The fruits were rinsed with water, and both the fruit pulps and fruit peels were air dried. The dried pulps and peels were grinded separately into pulverized powder using a grinding machine for ease of extraction.

The powdered materials of Musa paradisiaca fruits (400 g each) were separately extracted exhaustively with ethanol using Soxhlet extractor at $25{ }^{\circ} \mathrm{C}$. The filtrates were concentrated using Rotary evaporator at $40{ }^{\circ} \mathrm{C}$. The percentage yields were $8.4 \%$ (fruit pulp) and $9.73 \%$ 
(fruit peel). The concentrated ethanol extracts were refrigerated prior to use.

\section{Animals \\ Wistar rats $(150-180 \mathrm{~g})$ were obtained from the Animals' House facility of the Faculty. The animals were acclimatized for 7 days prior to the study, and were fed with rat feed and clean water ad libitum. Guidelines followed in the handling of animals were in accordance with the ethical standards of the Institutional Animals Ethics Committee (IAEC), as adopted by the ethical committee of the Faculty of Basic Medical Science, Delta State University, Abraka, Nigeria.}

\section{Experimental Design}

The animals were divided into five (5) groups of six animals each:

- Group 1 - Normal saline (Control) $10 \mathrm{ml} / \mathrm{kg}$

- Group 2 - Musa paradisiac fruit pulp extract (MPF Pulp) $200 \mathrm{mg} / \mathrm{kg}$

- Group 3 - Musa paradisiac fruit pulp extract (MPF Pulp) $400 \mathrm{mg} / \mathrm{kg}$

- Group 4-Musa paradisiac fruit peel extract (MPF Peel) $200 \mathrm{mg} / \mathrm{kg}$

- Group 5 - Musa paradisiac fruit peel extract (MPF Peel) $400 \mathrm{mg} / \mathrm{kg}$

The experimental animals were administered the extracts orally daily for 14 days according to their body weights.

\section{Sample Collection}

At the end of the 14-days treatment period, the animals were anesthetized using chloroform. Blood samples were collected by cardiac puncture into labeled EDTA bottles for haematological analysis and liver function tests.

\section{Determination of Haematological Indices}

The method as described by Tietz (1976) and Baker et al. (1998) were used for determining the red blood cells (RBC) counts, haemoglobin ( $\mathrm{Hb})$ concentration, and haematocrit level.

\section{Determination of Liver Function Test}

Alkaline phosphatase (ALP), aspartate aminotransferase (AST), and alanine transaminase (ALT) in serum were determined according to methods described by Reitman and Frankel (1957) and Roy (1970).

\section{Statistical Analysis}

Results are presented as the mean \pm standard error of the mean (SEM). Data were analysed using one-way analysis of variance (ANOVA) followed by Tukey's post hoc test. P-values $<0.05$ were taken as significant.

\section{RESULTS AND DISCUSSION}

Effect of Ethanol Fruit Extracts of Musa Paradisiaca on Haematological Indices of Wistar rats

Figures 1-3 depict the effect of ethanol fruit extracts (pulp and peel) of Musa paradisiaca on the red blood cell count, haematocrit level, and haemoglobin concentration of normal Wistar rat. MPF Pulp and MPF Peel at a dose of $200 \mathrm{mg} / \mathrm{kg}$ had a non-significant $(\mathrm{P}>0.05)$ increase in red blood cell count when compared to the control, however, at $400 \mathrm{mg} / \mathrm{kg}$, there was a significant $(\mathrm{P}<0.05)$ increase in red cell count. High dose $(400 \mathrm{mg} / \mathrm{kg})$ of both fruit extracts significantly $(\mathrm{P}<0.05)$ increased the haematocrit level as compared to the control. There was a non-significant $(P>0.05)$ increase in haemoglobin concentration in the treated rats as compared to the control.

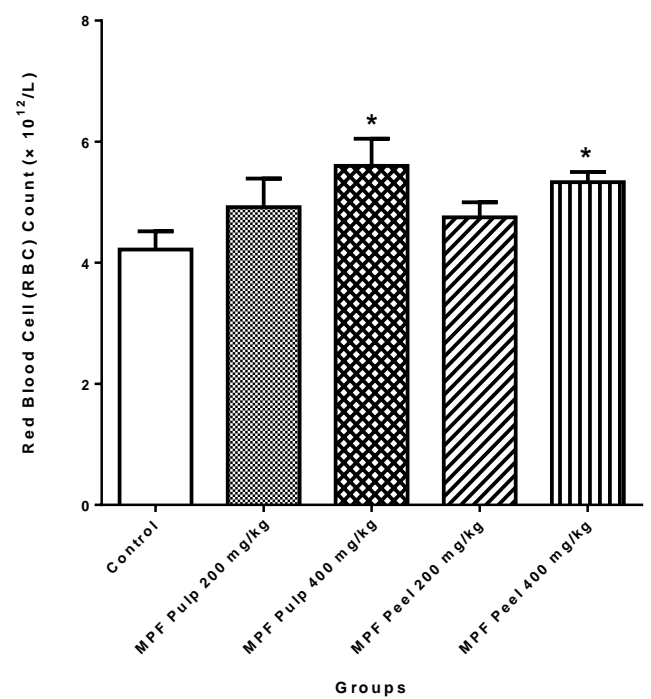

Figure 1. The effect of ethanol fruit extracts of Musa paradisiaca on red blood cell count of Wistar rats.

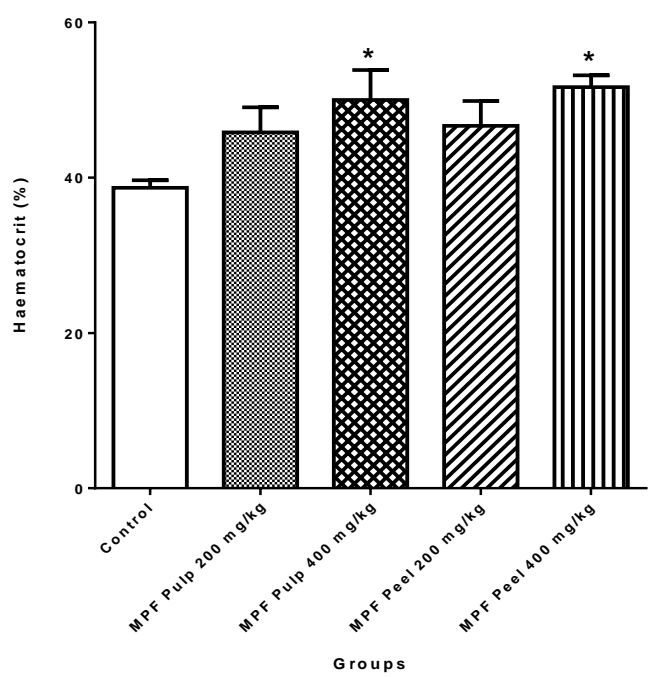

Figure 2. The effect of ethanol fruit extracts of Musa paradisiaca on haematocrit level of Wistar rats. 


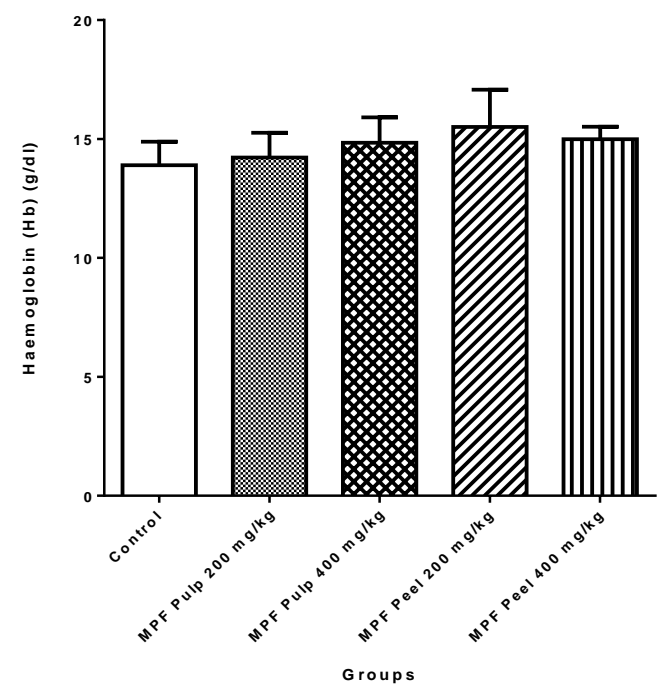

Figure 3. The effect of ethanol fruit extracts of Musa paradisiaca on heamoglobin concentration of Wistar rats.

Blood is composed of a variety of living cells that circulate through the heart and the blood vessels carrying nutrients, hormones, vitamins, antibodies, heat and oxygen to the body's tissue. The components of blood include red blood cells, white blood cells and platelets which are suspended in plasma (Basu and Kulkarni, 2014). Red cell contains haemoglobin, a protein that carries oxygen to all the tissues of the body. Haematocrit or packed cell volume is a measurement of the proportion of blood that is made up of cells. Following centrifugation, it is an estimate of the ratio of the volume of red blood cells to the total volume of blood (Mondal and Budh, 2020). Haematocrit and haemoglobin values are useful for assessing anaemia, polycythemia, and also for estimating response to treatment (Northrop-Clewes and Thurnham, 2013; White, 2018; Mondal and Budh, 2020). Hematopoiesis is the process involved in the formation of blood cells (Rieger and Schroeder, 2012). This study showed the positive effect of the fruit pulp and peel of Musa paradisiaca on hematopoiesis. Musa paradisiaca was also revealed to have to be non-toxic effect on liver enzymes.

The assessment of haemotological parameters could be used to reveal the deleterious effect of foreign compounds including plant extract on the blood constituent of animals. They can also be used to determine possible alteration in the levels of biomolecules, metabolic products, as well as histomorphology of the organs (Magalhães et al., 2008). Following the administration of the extracts, there was an increase in red cells count and haematocrit level, which was significant at a higher dose of $400 \mathrm{mg} / \mathrm{kg}$ as compared to the control group. MPF pulp had as better increase in red cell count when compared with MPF peel, whereas MPF peel showed a much effect in increasing the haemotocrit level as compared to MPF pulp. The results also revealed an increase in haemoglobin concentration (Figures 1-3). These increments indicate that $M$. paradisiaca contains phytochemicals that stimulate the synthesis of erythrocytes possibly by stimulating erythropoietin formation and secretion. Erythropoietin is a glycoprotein hormone which stimulates stem cells in the bone marrow to produce red blood cells (Ohlsson and Aher, 2009).

\section{Effect of Ethanol Fruit Extracts of Musa Paradisiaca on Serum Liver Enzymes of Wistar rats}

Figure 4 shows the effect of ethanol fruit extracts (pulp and peel) of Musa paradisiaca on the liver enzymes of normal Wistar rat. There was a non-significant $(\mathrm{P}>0.05)$ change in AST, ALT, and ALP level of the treated rats as compared to the control.

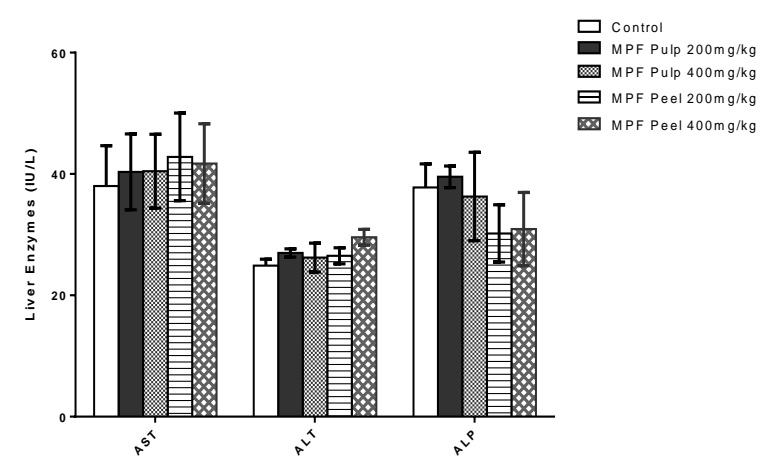

Figure 4. The effect of ethanol fruit extracts of Musa paradisiaca on liver enzymes of Wistar rats.

An assessment of the effect of ethanol fruit extracts of Musa paradisiaca on liver enzymes of Wistar rats showed a non-significant change in serum aspartate aminotransferase (AST), alanine aminotransferase (ALT) and serum alkaline phosphatase (ALP) levels of the treated rats as compared to the control (Figure 4). Serum AST, ALT, and ALP, which are cytoplasmic enzymes released into circulation after cellular damage are useful enzymes biomarkers in predicting liver damage (Ramaiah 2011; Zhao et al., 2018). ALT and AST are largely used in the assessment of liver damage by drugs or any other hepatotoxins, while ALP is a marker enzyme for the plasma membrane and endoplasmic reticulum (Giannini et al., 2005; McGill, 2016). The observed non-significant differences in the liver enzymes are an indication that both fruit pulp and peels extracts of Musa paradisiaca are non-toxic to the hepatic cells, thus, suggesting that Musa paradisiaca fruit extracts may not possess hepatotoxic effects, perhaps, a protective effect by stabilization of plasma membrane thereby preserving the structural integrity of the cell (Pari and Murugen, 2004). This is corroborated by the findings of Iweala et al (2011) which reported significantly reduced liver enzymes level with the consumption of a Musa paradisiaca-supplemented diet by Wistar rats. The hepatoprotective properties of Musa 
paradisiaca against experimentally induced hepatotoxic models have also been reported (Nirmala et al., 2012)

\section{CONCLUSION}

This study evaluated the effect of ethanol fruit extracts of Musa paradisiaca on haematological indices and serum liver enzymes. Fruit pulp and peel of Musa paradisiaca improve erythrocytes count and haematocrit level, and they may not be associated with liver toxicity. Fruits of Musa paradisiaca can be used as food therapy in raising red cells synthesis in anaemic conditions.

Conflict of Interest: The authors declare that there are no conflicts of interest concerning the publication of this article.

\section{REFERENCES}

Agarwal PK, Singh A, Gaurav K, Goel S, Khanna HD, Goel RK (2009). Evaluation of wound healing activity of extracts of plantain banana (Musa sapientum var. paradisiaca) in rats. Indian J Exp Biol 47: 322-40.

Baker FI, Silverton RE, Pallister CJ (1998). Baker and Silvertons Introduction to Medical Laboratory Technology, 7th edition, Bounty Press Ltd, Nigeria, 339-373.

Basu D, Kulkarni R (2014). Overview of blood components and their preparation. Indian J Anaesth 58(5): 529-37.

Benzie IFF, Wachtel-Galor S (2011). Herbal Medicine: Biomolecular and Clinical Aspects. 2nd edition, CRC Press/Taylor \& Francis, Boca Raton (FL).

Ekor M (2014). The growing use of herbal medicines: issues relating to adverse reactions and challenges in monitoring safety. Front Pharmacol 4:177.

Emudainohwo JOT, Erhirhie EO, Moke EG, Edje KE (2015). A Comprehensive Review on Ethno-Medicine, Phytochemistry and Ethnopharmacology of Chrysophyllum albidum. Journal of Advances in Medical and Pharmaceutical Sciences 3(4): 147-154

Ezekwesili CN, Ghasi S, Adindu CS, Mefoh NC (2014). Evaluation of the anti-ulcer property of aqueous extract of unripe Musa paradisiaca Linn. peel in Wistar rats. African Journal of Pharmacy and Pharmacology 8(39): 1006-1011.

Fagbemi JF, Ugoji E, Adenipekun T, Adelowotan O (2009). Evaluation of the antimicrobial properties of unripe banana (Musa sapientum L.), lemon grass (Cymbopogon citratus S.) and turmeric (Curcuma longa L.) on pathogens Afr J Biotechnol 8(7): 1176-1182.

Giannini EG, Testa R, Savarino V (2005). Liver enzyme alteration: a guide for clinicians. CMAJ 172(3): 367-79.

Issa MT, Agbon AN, Balogun SU, Mahdi O, Bobbo KA, Ayegbusi FO (2018). Hepatoprotective effect of methanol fruit pulp extract of Musa paradisiaca on carbon tetrachlorideinduced liver toxicity in Wistar rats. J Exp Clin Anat 17: 1-7

Iweala EEJ, Obichi IC, Omotosho OE (2011). Biochemical and Histological Responses of Hepatotoxic Rats Fed Musa paradisiaca L. Supplemented Diet. Int J Pharmacol 7(4): 471477.
Magalhães P, Appell H, Duarite J (2008). Involvement of advanced gyration and production pathogenesis of diabetes complication: The protective role of regular physical activity. Eur Rev Aging Phys Act 5: 17-29.

Mahomoodally MF (2013). Traditional Medicines in Africa: An Appraisal of Ten Potent African Medicinal Plants. Evid Based Complement Alternat Med, 617459.

McGill MR (2016). The past and present of serum aminotransferases and the future of liver injury biomarkers. EXCLI J 15: 817-828.

Moke EG, Anachuna KK, Edje KE, Ojezele MO (2019). Hepatoprotective effect of methanol seed extract of Citrus tangerina on paracetamol-induced hepatotoxicity in Wistar rats. Niger J Nat Prod Med, 2019, 23: 83-87.

Moke EG, Omorodion LI, Akpoguma HA, Imere P, Ahante E (2017). Anti-ulcerogenic Activity of Aqueous Extract of Unripe Fruit of Musa sapientum Linn in Combination with Vitamin $\mathrm{C}$ on Ulcer Induced Models in Experimental Rats. Eur J Med Plants 19(2): 1-6

Mondal H, Budh DP (2020). Hematocrit [Updated 2020 Jul 10]. In: StatPearls [Internet]. Treasure Island (FL): StatPearls Publishing; 2020 Jan-. Available from: https://www.ncbi.nlm.nih.gov/books/NBK542276/

Nayar NM. The bananas: botany, origin, dispersal. Hortic Rev, 2010, 36: 117-164.

Nirmala M, Girija K, Lakshman K, Divya T (2012). Hepatoprotective activity of Musa paradisiacal on experimental animal models. Asian Pac J Trop Biomed 2(1): 11-15.

Northrop-Clewes CA, Thurnham DI (2013). Biomarkers for the differentiation of anemia and their clinical usefulness. J Blood Med, 4: 11-22.

Ohlsson A, Aher SM (2006). Early erythropoietin for preventing red blood cell transfusion in preterm and/or low birth weight infants. Cochrane Database Syst Rev 3: CD004863.

Okafo SE, Moke EG, Obi CS (2019). Formulation and evaluation of anti-diabetic tablets containing aqueous extract of Moringa oleifera seeds. J Pharm Allied Sci 16(5): 3167-3176.

Onasanwo SA, Emikpe BO, Ajah AA, Elufioye TO (2013). Antiulcer and ulcer healing potentials of Musa sapientum peel extract in the laboratory rodents. Pharmacognosy Res 5(3): $173-8$.

Oyeyinka BO, Afolayan AJ (2019). Comparative Evaluation of the Nutritive, Mineral, and Antinutritive Composition of Musa sinensis L. (Banana) and Musa paradisiaca L. (Plantain) Fruit Compartments. Plants (Basel) 8(12): 598.

Pari L, Murugan P (2004). Protective role of tetrahydrocurcumin against erythromycin estolate-induced hepatotoxicity. Pharmacol Res 49(5): 481-6.

Ramaiah SK (2011). Preclinical safety assessment: current gaps, challenges and approaches in identifying translatable biomarkers of drug-induced liver. Clin Laboratory Med 31: 161-72.

Reitman S, Frankel S (1957). A colorimetric method for the determination of serum glutamic oxalacetic and glutamic pyruvic transaminases. American J Clin Path 28: 56-63.

Rieger, M. A., \& Schroeder, T. (2012). Hematopoiesis. Cold Spring Harbor perspectives in biology, 4(12), a008250. https://doi.org/10.1101/cshperspect.a008250. 
Roy AV (1970). Rapid method for determining alkaline phosphatase activity in serum with thymolphthalein monophosphate. Clin. Chem 21: 5.

Tietz NW (1976). Fundamental of clinical chemistry, 2nd edition, WB Saunders Co, Philadelphia, 411.

Uwaoma LA (2003). Sources of common medicinal plants used in Southern Nigeria. Sam Press, Enugu, 23.

Vilhena RO, Figueiredo ID, Baviera AM, Silva DB, Marson BM, Oliveira JA, Peccinini RG, Borges IK, Pontarolo R (2020). Antidiabetic activity of Musa $\mathrm{x}$ paradisiaca extracts in streptozotocin-induced diabetic rats and chemical characterization by HPLC-DAD-MS. J Ethnopharmacol 254: 112666.

White NJ (2018). Anaemia and malaria. Malar J 17: 371.

Yin X, Quan J, Kanazawa T (2008). Banana Prevents Plasma Oxidative Stress in Healthy Individuals. Plant Foods Hum Nutr 63: 71-76

Zhao Z, Chang J, Lin L, Tsan F, Chang H, Wu C. (2018). Comparison of the hepatoprotective effects of four endemic Cirsium species extracts from Taiwan on CCl4-induced acute liver damage in C57BL/6 mice. Int J Mol Sci 19(1329): 1-18. 
THIS PAGE INTENTIONALLY LEFT BLANK 